\title{
Chinese phytotherapy to reduce stress, anxiety and improve quality of life: randomized controlled trial
}

\author{
Fitoterapia chinesa para redução de estresse, ansiedade e melhoria \\ de qualidade de vida: ensaio clínico randomizado \\ Fitoterapia china para reducción de estrés, ansiedad y mejoría \\ de calidad de vida: ensayo clínico randomizado
}

Leonice Fumiko Sato Kurebayashi ${ }^{1}$, Ruth Natalia Teresa Turrini ${ }^{2}$, Gisele Kuba ${ }^{3}$, Miki Hoshi Minamizawa Shimizu ${ }^{4}$, Raymond Sehiji Takiguchi ${ }^{5}$

How to cite this article:

Kurebayashi LFS, Turrini RNT, Kuba G, Shimizu MHM, Takiguchi RS. Chinese phytotherapy to reduce stress, anxiety and improve quality of life: randomized controlled trial. Rev Esc Enferm USP. 2016;50(5):853-860. DOI: http://dx.doi.org/10.1590/S0080-623420160000600020

${ }^{1}$ Universidade de São Paulo, School of Nursing, Post-doctoral program, São Paulo, SP, Brazil.

${ }^{2}$ Universidade de São Paulo, School of Nursing, Medical Surgical Nursing Department, São Paulo, SP, Brazil.

${ }^{3}$ Universidade de São Paulo, School of Nursing, Graduate program, São Paulo, SP, Brazil.

${ }^{4}$ Integrated and Eastern Therapy Institute, São Paulo, SP, Brazil.

${ }^{5}$ Universidade de São Paulo, Institute of Biological Sciences, São Paulo, SP, Brazil.

\section{ABSTRACT}

Objective: To evaluate the effect of Chinese phytotherapy to reduce stress levels, anxiety and improve quality of life. Method: double-blind randomized controlled trial with 89 volunteers divided into three groups: control (no intervention), Placebo and Phytotherapy. The study was conducted in 2015 with healthy adults treated at the Integrated and Eastern Therapy Institute, in Sao Paulo, Brazil. Participants were evaluated at baseline and after three weeks with the Stress Symptoms List (SSL), Anxiety Inventory-Trait and State and SF12v2 for quality of life. Intervention groups received a placebo or Gan May Zao formula (GMDZ) flask with $50 \mathrm{ml}$. Results: According to ANOVA, there were significant differences $(\mathrm{p}=0.025)$ after treatment of stress (SSL2). And the difference was between control and Phytotherapy groups, according to the Tukey post hoc ( $p=$ 0.022). There were no differences in the levels of state-anxiety and physical and mental domains in the SF12v2. Conclusion: The GMDZ formula reduced stress levels, but more studies are needed with greater sample, with reassessment of dosage and a longer period of treatment to confirm and extend the results. Brazilian Registry of Clinical Trials: RBR-28s4hz.

\section{DESCRIPTORS}

Phytotherapy; Stress, Psychological; Anxiety; Medicine, Chinese Traditional. 


\section{INTRODUCTION}

Stress is present in the daily lives of people in at least $90 \%$ of the population ${ }^{(1)}$ and it is known that continuous stress can cause numerous pathophysiological effects on physical and mental health and can lead to disorders such as depression and anxiety ${ }^{(2)}$. Oriental therapies seek, above all, to promote wellness and prevent diseases, with benefits for early intervention through the combination of therapies and customizing the service ${ }^{(3)}$.

In fact, the "Strategy of the World Health Organization (WHO) on Traditional Medicine 2014-2023" set as one of its goals, the expansion of the use by State Members, regarding Traditional Chinese Medicine knowledge to improve the health, well-being of populations and the patients centered outcome. The development of research on safety and efficacy of the techniques for incorporation of products, professional and therapeutic in public health systems of different countries was emphasized as criti$\mathrm{cal}^{(4)}$. In this sense, the use of phythotherapy has been suggested in the treatment of most different conditions and diseases for millennia in China ${ }^{(5)}$, but the assessment of the effects and mechanisms of action need to be further studied and recognized.

In 2005, the WHO global survey on the National Policy on Traditional Medicine and Phytotherapy Regulations had already shown an increase in the use of complementary and alternative medicine in many developed and developing countries. The safety and efficacy of such practices and quality control have become important concerns. Thus, the preparations of Chinese formulas have followed the standard of Good Practice in Chinese Medicine ${ }^{(6)}$.

The decoction Gan Mai Da Zao (GMDZ) is a Chinese formula widely used for depression in East $\mathrm{Asia}^{(7)}$ and has been commonly recognized as a safe and effective prescription for the treatment of these mental disorders in China ${ }^{(8)}$. It has also demonstrated to have a protective effect on biochemical alterations in the chronic mild stress induced in mice, and decreased levels of glutamate and increasing NMDA receptor expression in the NR2a and NR2b subunit in the frontal cortex and hippocampus in stressed mice ${ }^{(9)}$.

According to Traditional Chinese Medicine (TCM), the GMDZ formula is suitable for TCM diagnoses, such as irritability syndrome of Zhang organs due to blood deficiency in the Heart (Xin) and Stagnation of Liver Qi (Gan): for the symptoms irritability, anxiety, depressive episodes followed by crying, insomnia, sleepwalking, epilepsy and neurasthenia. The tongue in general appears red with little coating and fast and fine pulse ${ }^{(10)}$.

The ingredients of Gan Mai Da Zao include the following herbs: Radix Glycyrrbiza uralensis Fisch (Licorice $\mathrm{Gan} \mathrm{Cao}$ ), Triticum aestivum Levis (Wheat - Fu Xiao Mai) and Fructus Zizyphus Jujubae (Jujube - Da Zao). Radix Glycyrrbizae (Gan Cao) has a sweet and neutral taste, it nourishes the $\mathrm{Q} i$, the Heart and the Spleen $(\mathrm{Pi})$, eliminating spasms. Wheat (Fu Xiao Mai) has a sweet and salty taste of fresh nature and it nourishes Heart Yin and harmonizes the mind. The Fructus Zizyphi or jujube (Da Zao) is sweet, has warm nature tones Middle Burner, it nourishes the Blood and the Qi, relaxes and harmonizes the liver, as well as moisturizing the Zang (viscera). Therefore, the main actions of GMDZ are: nourishment of the heart, calming the Shen, harmonizing Jiao Medium, toning the Spleen Qi and calming the impatience ${ }^{(11)}$.

With regard to stress, this is not necessarily negative, since it is a common event of daily life and all organisms have developed mechanisms to deal with it. Besides that, it can be stimulating and motivating. The problem is its intensity, length and when it exceeds the individual's ability to adapt. According to neurobiology of stress, there is a response to the stressor element characterized by four main aspects: avoidance behavior, increased surveillance, activation of the Sympathetic Vegetative Nervous System, and finally release of cortisol by the adrenal glands ${ }^{(12)}$.

When excessive, stress causes an imbalance in the neural circuit that interferes with cognition, decision making, anxiety and mood, creating changes in behavioral states. Exposure to continuous stress leads to numerous physiological effects, with the activation of neuroendocrine functions in adrenal, limbic, hypothalamic and pituitary systems ${ }^{(13-14)}$ and hormonal functions, with the release of corticosteroids ${ }^{(15)}$. The hormone cortisol, in turn, is released by the adrenal gland cortex in response to increased blood levels of adrenocorticotropic hormone (ACTH), which is released by the anterior pituitary in response to corticotropin releasing hormone (CRH). When the information reaches the region of the basolateral amygdala, it is processed and transmitted to the central nucleus neurons. Upon reaching the nucleus, the stress response leads to an inappropriate activation of the amygdala, which may be related to anxiety episodes. We should consider that continuous exposure to cortisol can lead to dysfunction and death of hippocampal neurons, creating a vicious circle in which the stress response becomes more pronounced, leading to increased cortisol release and further damage to the hippocampus ${ }^{(12)}$.

Finally, stress interferes with quality of life and can change the way a person reacts to different areas of his or her life. The quality of life is related not only to the health field, but also the social, emotional and professional area. In 1947, the WHO defined health as a state of physical, mental and social well-being and not merely the absence of disease or disease and thus, introducing the idea of quality of life, emphasizing its multidimensional character ${ }^{(16)}$. The quality of life was defined, therefore, as the perception of individuals of their position in life, in cultural context and value system in which they live, and in relation to their goals, expectations, standards and concerns ${ }^{(17)}$.

Due to the above, this study was conducted to compare the effects of Gan Mai Da Zao in a Control group and a placebo group, in reducing levels of stress, anxiety and improving quality of life. The experiment was conducted in healthy subjects, which showed moderate to high levels of stress and anxiety cared at the Integrated and Eastern Therapy Institute in the city of Sao Paulo. We also sought to evaluate the symptoms that best responded to treatment and possible TCM diagnoses related to the symptoms. 


\section{METHOD}

This is a parallel, double-blind, randomized controlled trial. The research was conducted in an outpatient clinic at Integrated and Eastern Therapy Institute (IETI) from June to August 2015. We invited volunteers from IETI to participate in the study that had medium and high levels of stress, according to the Stress Symptoms List (LSS, 37-120 points). Pregnant women, individuals who were on holiday leave during the research period were excluded; we also excluded those who started using allopathic medicines for anxiety and antidepressants or initiate other energy therapies during the research. However, we did not exclude those already performing psychological therapy, with the condition to continue their treatment normally.

After participants' inclusion, a random division was made in three different groups, using the Research Randomizer Quick Tutorial program control group - G1 (no intervention), Placebo Group - G2, Phytotherapy Group - G3 The Phytotherapy and placebo groups received one Chinese herb bottle or placebo and took 15 drops three times a day, dissolved in water, in the morning, afternoon and evening, for the period of 3 weeks. The flasks were previously prepared by a compounding pharmacy and all containers were equal and received a number (1 or 2 ) to allow the blinding of both for participants as well as for the researcher.

The sample size calculation was originally proposed for 90 individuals with a power of $80 \%$ and $95 \%$ confidence interval. However, the eligible population obtained was 89 individuals and 71 completed the study. Regarding losses, 14 did not attend the second assessment or failed to maintain the regularity of the use of Phytotherapy or placebo; two began acupuncture therapy and two were on Holydays at the same period (Figure 1).

All participants answered a biologic sociodemographic questionnaire and instruments: Stress Symptoms List (LSS) ${ }^{(18)}$, State-Trait Anxiety Inventory ${ }^{(19)}$ and SF12v2 for Quality of life ${ }^{(20)}$, applied at the beginning of the research and after three weeks of treatment.

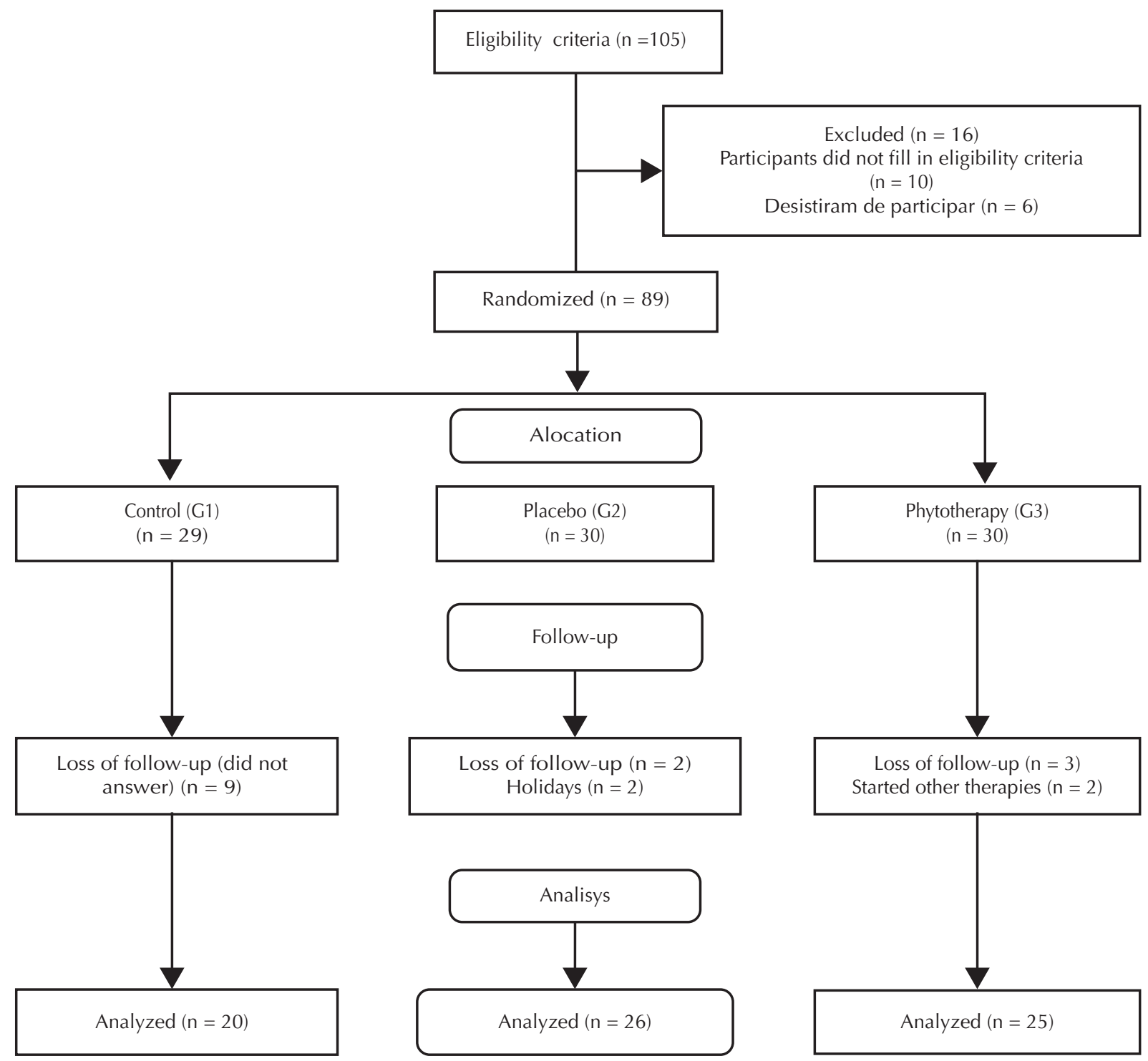

Figure 1 - Flowchart of participants involved in the study - Sao Paulo, SP, Brazil, 2015. 
As a protocol for Phytotherapy group we used GMDZ formula consisting in three herbs: (1) Radix Glycyrrbiza uralensis Fisch (Licorice - Gan Cao), (2) Triticum aestivum Levis (Wheat - Fu Xiao Mai) and (3) Fructus zizyphus Jujubae (Jujube - Da Zao). The control group received 30\% alcoholic solution (Mineral Water, brandy), basis generally used for herbal composition formulas.

The study met the resolution 466/12 of the Brazilian National Health Council for research involving human subjects, participants signed the Informed and Consent form. We offered the opportunity to receive Chinese Phytotherapy after the conclusion of the research to the participants in the control and placebo groups. The research project was approved by the Research Ethics Committee of the School of Nursing of the Universidade de São Paulo (No. 1,105429) and it was registered by the Brazilian Registry of Clinical Trials (No. RBR-28s4hz).

For descriptive analysis of the data, we used central tendency and absolute and relative frequencies, Cronbach's alpha to assess the reliability of the scales used and for comparison of groups, we used ANOVA for repeated measures with Tukey post-hoc. We also used the Cohen's d index to measure the effect size.

\section{RESULTS}

The mean age of participants was 37 years $( \pm 11.4), 69.0 \%$ (49) were female, $66.2 \%$ (47) were single, $73.2 \%$ (52) had college education, $74.6 \%$ (53) with no history of prior disease and high levels of stress $(67.7 \pm 19.3)$. Some comorbidities were reported as: osteoarthritis (2), back problems (2), the patellar chondromalacia (1), depression (2), dermatitis (1), sinusitis (1), bronchitis (1), diabetes mellitus (1), gastritis (2), panic (1), and postsurgical sequelae (1). Two (2.8\%) participants were on psychological therapy during the period of investigation.

There was homogeneity in the distribution between the study groups regarding age, gender, stress levels, people with and without pre-conditions, marital status and educational level $(\mathrm{p}>0.05)$.

Table 1 presents the descriptive measures of the scores obtained in the LSS, STAI, physical domain (SF12P), mental domain (SF12M) before (1) and after treatment (2) and comparative analysis between groups (ANOVA).

Table 1 - Descriptive means and standard deviation levels of stress, STAI and physical domain (SF12P), mental domain (SF12M) before and after treatment in the three groups and intergroup ANOVA - Sao Paulo, SP, Brazil, 2015.

\begin{tabular}{|c|c|c|c|c|c|}
\hline Instruments & Groups & $\mathbf{n}$ & mean & SD & p \\
\hline \multirow{4}{*}{ LSS-1 } & Control & 20 & 67.1 & 15.5 & \\
\hline & Placebo & 26 & 69.5 & 23.4 & \\
\hline & Phytotherapy & 25 & 66.2 & 17.8 & \\
\hline & ANOVA & 71 & 67.7 & 19.3 & 0.821 \\
\hline \multirow{4}{*}{ LSS-2 } & Control & 20 & 70.4 & 15.5 & \\
\hline & Placebo & 26 & 58.1 & 25.1 & \\
\hline & Phytotherapy & 25 & 54.0 & 17.2 & \\
\hline & ANOVA & & & & $0.025^{*}$ \\
\hline \multirow{4}{*}{ STAI S-1 } & Control & 20 & 50.2 & 11.1 & \\
\hline & Placebo & 26 & 51.7 & 12.4 & \\
\hline & Phytotherapy & 25 & 51.1 & 10.3 & \\
\hline & ANOVA & & & & 0.900 \\
\hline \multirow{4}{*}{ STAI S-2 } & Control & 20 & 50.4 & 11.1 & \\
\hline & Placebo & 26 & 45.8 & 10.9 & \\
\hline & Phytotherapy & 25 & 47.2 & 11.2 & \\
\hline & ANOVA & & & & 0.374 \\
\hline \multirow{4}{*}{ SF12 P-1 } & Control & 20 & 48.3 & 10.1 & \\
\hline & Placebo & 26 & 50.3 & 9.4 & \\
\hline & Phytotherapy & 25 & 47.7 & 8.8 & \\
\hline & ANOVA & & & & 0.588 \\
\hline \multirow{4}{*}{ SF12 P-2 } & Control & 20 & 48.4 & 11.2 & \\
\hline & Placebo & 26 & 52.5 & 7.6 & \\
\hline & Phytotherapy & 25 & 49.8 & 7.8 & \\
\hline & ANOVA & & & & 0.271 \\
\hline
\end{tabular}


...continuation

\begin{tabular}{|c|c|c|c|c|c|}
\hline Instruments & Groups & $\mathbf{n}$ & mean & SD & $\mathbf{p}$ \\
\hline \multirow{4}{*}{ SF12 M-1 } & Control & 20 & 39.2 & 13.3 & \\
\hline & Placebo & 26 & 35.9 & 10.5 & \\
\hline & Phytotherapy & 25 & 36.8 & 10.8 & \\
\hline & ANOVA & & & & 0.618 \\
\hline \multirow{4}{*}{ SF12 M-2 } & Control & 20 & 40.3 & 12.2 & \\
\hline & Placebo & 26 & 41.0 & 12.9 & \\
\hline & Phytotherapy & 25 & 42.3 & 11.3 & \\
\hline & ANOVA & & & & 0.848 \\
\hline
\end{tabular}

$* p<0.05$ (ANOVA for repeated measures).

The result of Cronbach's alpha test for LSS was 0.92; 0.94 for state-anxiety and 0.88 for trait-anxiety. At baseline, the mean score of trait-anxiety was 47.9 and state-anxiety was 51.1, both considered moderate level of anxiety. For LSS, the baseline mean was 66.7 (high stress level), the physical domain of the SF12 was 48.8 and mental domain was 37.1. It has been recommended for this instrument that the interpretations should be based on means considered normal score in US healthy population of 50 and a standard deviation of $10^{(20)}$.

In the analysis of repeated measures (ANOVA), there was a statistically significant difference $(p=0.025)$ in the assessment of LSS after treatment and this difference occurred only between control and Phytotherapy groups, according to the Tukey post hoc $(p=0.022)$. There were no differences in the levels of state-anxiety (STAI S) and physical and mental domain of SF12 between any of the groups. The trait-anxiety, on the other hand, was not evaluated at the end of the study. It is understood that the trait-anxiety is a relatively stable and permanent feature in the individual ${ }^{(19)}$.

Also Cohen index $\mathrm{d}$ for the three groups and the percentage change for all three groups were defined between before and after treatment. The placebo group reached 16.0\% reduction, with Cohen's d index 2.4 (great effect) and Phytotherapy Group reached $18.0 \%$ reduction, with Cohen index d 3.5 (great effect).

ANOVA was performed for repeated measures and multiple Tukey comparisons between before-after treatment for each LSS symptoms (Table 2) and only the symptoms presented in Table 2 showed statistical differences between before and after treatment.

The symptoms that best responded to the treatment of Phytotherapy were: "I feel nausea" (68.0\% reduction), "my appetite fluctuates a lot" (41.0\%), "I forget things" (18.0\%) "I feel physical exhaustion" (28.0\%) and "I have nightmares" (28.0\%). The reduction of symptoms "I forget things" (18.0\%) and "I have nightmares" (28.0\%) was observed only in phytotherapy group.

The symptoms that responded only to Placebo were: "everything terrifies me" (32.0\%) and "I worry" (25.0\%). The symptom "I feel nauseous" also responded to the placebo group with $18.0 \%$ and "my appetite fluctuates a lot" with $23.0 \%$ reduction.

The side effects observed with the use of GMDZ were mild bloating, acid regurgitation and somnolence. But that was no reason for participants to leave the study.

\section{DISCUSSION}

Positive results were found for Phytotherapy Group regarding the stress levels. As already noted, the GMDZ formula has three components, including Licorice (Gycyrrhiza). Studies on Licorice (Gycyrrbiza) or Gan Cao (Glycyrrbiza uralensis) indicate that the main active ingredient is the glycyrrhizic acid ${ }^{(21)}$, a potent inhibitor of $11 \beta$-hydroxyster-

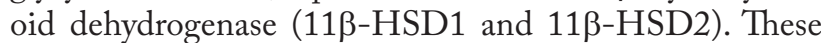
isoenzymes are fundamental in cortisol metabolism ${ }^{(22)}$, which in turn is associated with an increased propensity to develop distress and depression. Another herb, the fruit of the jujube (Ziziphus jujube), is also widely used in China for treating insomnia and anxiety. Its main bio-component Jujubogenina, which the main component is Jujuboside A (JuA). Studies indicate that JuA has direct action on the glutamatergic system in the hippocampus through the inhibition of glutamate via modulation of $\mathrm{CaM}$ kinase ${ }^{(23)}$, which implies a quick action against deleterious effects of stress.

Table 2 - Stress symptoms between groups, according to $p$ values by ANOVA and Tukey, and Cohen index d - Sao Paulo, SP, Brazil, 2015.

\begin{tabular}{|c|c|c|c|c|}
\hline & $\underset{P}{\text { ANOVA }}$ & $\begin{array}{c}\text { Tukey } \\
p\end{array}$ & $\begin{array}{c}\text { G2 - G1 } \\
\text { Cohen's d (\%) }\end{array}$ & $\begin{array}{c}\text { G3 - G1 } \\
\text { Cohen's d (\%) }\end{array}$ \\
\hline Everything frightens me & 0.031 & G2-1 (0.023) & $0.42(33.0)$ & - \\
\hline I feel nausea & 0.000 & G2-1 (0.004); G3-1(0.000) & $0.17(19.0)$ & $0.8(68.0)$ \\
\hline I forget things & 0.006 & G3-1 (0.004) & - & $0.29(18.0)$ \\
\hline I feel physical exhaustion & 0.031 & G2-1(0.049); G3-1 (0.05) & $0.36(23.0)$ & $0.68(28.0)$ \\
\hline I worry & 0.031 & G2-1 (0.028) & $0.69(26.0)$ & - \\
\hline I have nightmares & 0.042 & G3-1(0.035) & - & $0.28(28.0)$ \\
\hline My appetite fluctuates a lot & 0.003 & G2-1(0.004); G3-1(0.000) & $0.28(23.0)$ & $0.36(41.0)$ \\
\hline
\end{tabular}


According to the ERM, the treatment reduced the levels of various symptoms related to the Heart (Xin), such as forgetting $(\mathrm{d}=18.0 \%)$ and nightmares $(\mathrm{d}=28 \%)$ for Group 3 . These may be related to deficiency of Qi and Xue (blood) from the Heart and consequent disturbance of the Shen (Mind). In fact, all the Yin organs may be involved. As the Heart (Xin), the Spleen $(\mathrm{Pi})$ can be damaged by overwork or concerns ${ }^{(24)}$. Symptoms related to deficiency of $\mathrm{Qi}$ and Xue (Blood) Spleen $(\mathrm{Pi})$ which obtained a reduction after treatment were nausea $(\mathrm{d}=68 \%)$ and oscillating appetite $(d=41 \%)$. Fire derived from Liver Qi may also be involved in the failure of Yin, with the appearance of nightmares. And finally, if there is Kidney failure (Shen) and Lungs failure (Fei) emerge the general weakness of Qi and Yin ${ }^{(25)}$, affecting all systems, causing the individual to feel exhaustion, which was decreased by $28.0 \%$ in the phytotherapy group.

In contrast, the placebo group also achieved good results in some mental and physical symptoms. Psychological symptoms of "everything terrifies me" and "I worry" reached $32.0 \%$ and $35.0 \%$ reduction respectively; and physical symptoms, "I feel nausea" $(\mathrm{d}=19.0 \%)$, "I feel physical exhaustion" $(\mathrm{d}=23.0 \%)$ and "oscillating appetite" $(\mathrm{d}=23 \%)$ were also reduced, which led to an inevitable question. Why did a placebo solution produce positive effects on the reduction of symptoms? Could the effects be kept in a longer treatment time?

For many years, placebos were defined by their inert content being used as a control mechanism in clinical trials and treatments in clinical practice. Recent studies show, however, that the placebo effects are Psychobiological events attributable to the overall therapeutic context, and that such effects can be robust in clinical and laboratory settings ${ }^{(26)}$. To understand the placebo phenomenon, it is necessary to differentiate it from other non-specific factors, such as: the natural course of the disease, fluctuations in symptoms, regression to the mean, the time of the disease, a subjective response bias of the patient, among others. Although it lacks a specific pharmacological effect, it is known today that placebos may act therapeutically and impact patient's imagination, beliefs, expectations, emotions and past experiences ${ }^{(27)}$.

There are neurobiological and psychological mechanisms involved in the placebo effect and there are two main theoretical structures proposed to explain it: (1) the mentalistic theory, according to which the expectation of the individual is the main basis for the placebo effect, and (2) the conditioning theory, which indicates that placebo is essentially the result of previous experiments and results of associative learning processes (conditioned response) (26). Based on this, we question whether the belief of the participants in the benefits and feel cared were determinants in producing the effects, even if they knew which groups receive a placebo solution. In fact, an affective communication (warmth, empathy, eye contact), as offered in customer service can produce satisfaction, patient compliance and positive effects on health, regardless of a medication or procedure performed ${ }^{(28)}$.

Given the complexity of the placebo effect, it would have been important to assess how much they thought they were taking the real drug or placebo. In this sense, to understand how expectations can be crucial, a study was carried out with a radically different approach to Parkinson's patients for the management of pain and anxiety. The objective of the study was to recognize the administration and withdrawal of drugs open or closed so patients could produce a different effect with respect to the usual medications of pain and anxiety, offered intravenously. And it was concluded that, in fact, open and informed treatment, with patients aware of medications to which they were being subjected achieved better results than those completely unaware patients receiving medications ${ }^{(29)}$.

The placebo effect seems to act on various neurotransmitter systems, such as opioid and dopamine. Brain regions including anterior cingulate cortex, dorsolateral prefrontal cortex and basal ganglia can be activated after placebo administration. The expected improvement in a patient may therefore influence the results, as well as some active intervention, and this effect may be greater for procedures ${ }^{(30)}$.

Some considerations need to be made in relation to the limitations of this study. Perhaps the three weeks' period was relatively short to achieve the desired results and the proposed dosage, consisting of only 15 drops three times daily may be insufficient to reduce anxiety and improve quality of life. The main limitation of this study was the number of people who managed to complete the study. We did not reach the expected number (30) per group, determined by sample size calculation and the findings should be carefully considered.

\section{CONCLUSION}

The results suggest that stress levels were reduced with the use of GMDZ formula compared to the control group, although no differences were found between Phytotherapy and Placebo Group. There was no intergroup differences in the levels of anxiety-state and quality of life (SF12). For symptoms of stress that improved after treatment with GMDZ, it is suggested that the formula is indicated for the TCM diagnostics association: Heart Deficiency (Xin) and Shen Perturbation (mind), Qi Stagnation of Liver (Gan) for Qi deficiency and Blood Spleen (Pi) and Qi deficiency and Yin General. However, more studies are needed with a greater sample size, a reassessment of the dosage, the period of treatment and the use of physiological markers of stress, so that the results may be confirmed and extended to other populations. 
Foi realizado em 2015, com adultos saudáveis atendidos no Instituto de Terapia Integrada e Oriental, São Paulo. Foram avaliados no baseline e, após 3 semanas, pela Lista de Sintomas de Stress (LSS), Inventário de Ansiedade-Traço e Estado e o SF12v2 de qualidade de vida. Os grupos de intervenção receberam um frasco de $50 \mathrm{ml}$ de placebo ou da fórmula Gan Mai Da Zao (GMDZ). Resultados: Segundo ANOVA, houve diferença $(p=0,025)$ no pós-tratamento de estresse (LSS2). E a diferença foi entre os grupos Controle e Fitoterapia, de acordo com o post hoc de Tukey $(p=0,022)$. Não houve diferenças nos níveis de ansiedade-estado e domínio físico e mental do SF12v2. Conclusão: A fórmula GMDZ reduziu os níveis de estresse, mas são necessários mais estudos com amostra significativa, com reavaliação da posologia e um período maior de tratamento para confirmar e ampliar os resultados. Registro Brasileiro de Ensaios Clínicos: RBR-28s4hz.

\section{DESCRITORES}

Fitoterapia; Estresse Psicológico; Ansiedade; Medicina Tradicional Chinesa.

\section{RESUMEN}

Objetivo: Evaluar el efecto de la fitoterapia china en la reducción de los niveles de estrés, ansiedad y mejoría de calidad de vida. Método: Ensayo clínico aleatorizado, doble ciego, con 89 voluntarios divididos en tres grupos: Control (sin intervención), Placebo y Fitoterapia. Se realizó en 2015, con adultos sanos atendidos en el Instituto de Terapia Integrada y Oriental, São Paulo. Fueron evaluados en el baseline y, después de 3 semanas, por el Listado de Síntomas de Estrés (LSE), Inventario de Ansiedad Rasgo-Estado y el SF12v2 de calidad de vida. Los grupos de intervención recibieron un frasco de $50 \mathrm{ml}$ de placebo o la fórmula Gan Mai Da Zao (GMDZ). Resultados: Según ANOVA, hubo diferencia $(p=0,025)$ en el post tratamiento de estrés (LSE2). Y la diferencia fue entre los grupos Control y Fitoterapia, de acuerdo con el post hoc de Tukey $(p=0,022)$. No hubo diferencias en los niveles de ansiedad-estado y dominio físico y mental del SF12V2. Conclusión: La fórmula GMDZ redujo los niveles de estrés, pero son necesarios más estudios con muestra significativa, con reevaluación de la posología y un período mayor de tratamiento para confirmar y ampliar los resultados. Registro Brasileño de Ensayos Clínicos: RBR-28s4hz.

\section{DESCRIPTORES}

Fitoterapia; Estrés Psicológico; Ansiedad; Medicina China Tradicional.

\section{REFERENCES}

1. Organización Mundial de la Salud (OMS). La organización del trabajo y el estrés: estrategias sistemáticas de solución de problemas para empleadores, personal directivo y representantes sindicales. Ginebra: OMS; 2004.

2. Maes M, Kubera M, Obuchowiczwa E, Goehler L, Brzeszcz J. Depression's multiple comorbities explained by(neuro)inflammatory and oxicdative and nitrosative stress pathways. Neuro Endocrinol Lett. 2011;32(1):7-24.

3. Wang X, Sun H, Zhang A, Sun W, Wang P, Wang Z. Potential role of metabolomics approaches in the area of traditional Chinese medicine: as pillars of the bridge between Chinese and Western medicine. J Pharm Biomed Anal. 2011;55(5):859-68.

4. World Health Organization (WHO). Tradicional medicine Strategy: 2014-2023. Geneva: WHO; 2014.

5. Alvim NAT, Ferreira MA, Cabral IE, Filho AJA. O uso de plantas medicinais como recurso terapêutico: das influências da formação profissional às implicações éticas e legais de sua aplicabilidade como extensão da prática de cuidar realizada pela enfermeira. Rev Lat Am Enfermagem. 2006;14(3):1-9.

6. Fan TP, Deal G, Koo HL, Rees D, Sun H, Chen S, et al. Future development of global regulations of Chinese herbal products. Journ Ethnopharmacol. 2012;140(3):568-86.

7. Jun JH, Choi TY, Lee JA, Yun KJ, Lee MS. Herbal medicine (Gan Mai Da Zao decoction) for depression: a systematic review and metaanalysis of randomized controlled trials. Maturitas. 2014;79(4):370-80.

8. Guo JY, Huo HR, Li LF, Guo SY, Jiang TL. Sini tang prevents depression-like behavior in rats exposed to chronic unpredictable stress. Am J Chin Med. 2009;37(2):261-72.

9. Lou JS, Li CY, Yang XC, Fang J, Yang YX, Guo JY. Protective effect of gan mai da zao decoction in Unpredictable chronic mild stress-induced behavioral and biochemical alterations. Pharm Biol.2010;48(12):1328-36.

10. Cheng LD. Fórmulas magistrais chinesas. São Paulo: Roca; 2008.

11. García FM. Colección de la Fundación Europea de Medicina Tradicional China: materiales académicos de medicina China. Amposta (Tarragona): Fundación Europea de MTC; 2012.

12. Bear MF, Connors BW, Paradiso MA. Neurociências, desvendando o sistema nervoso. $3^{\text {a }}$ ed. São Paulo: Artmed; 2008.

13. McEwen BS, Gray JD, Nasca C. Redefining neuroendocrinology: stress, sex and cognitive and emotional regulation. J Endocrinol. 2015;226(2):T67-83.

14. Bonfiglio JJ, Inda C, Refojo K, Holsboer F, Arzt E, Silberstein S. The corticotropin-releasing hormone network and the hypothalamicpituitary-adrenal axis: molecular and cellular mechanisms involved. Neuroendocrinology. 2011;94(1):12-20.

15. Rocha MCP, De Martino MMF, Grassi-Kassisse DM, Souza AL. Stress among nurses: na examination of salivar cortisol levels on work and day off. Rev Esc Enferm USP. 2013;47(5):1194-01.

16. Kimura M, Ferreira KASL. Avaliação da qualidade de vida em indivíduos com dor. In: Leão ER, Chaves LD. Dor: $5^{\circ}$ sinal vital: reflexões e intervenções de Enfermagem. Curitiba: Maio; 2004. p. 59-74. 
17. World Health Organization; Mental Health Evidence and Research Department of Mental Health and Substance Dependence. WHOQOL-HIV Instrument: users manual [Internet]. Geneva: WHO; 2002 [cited 2015 Jan 30]. Available from: http://apps.who.int/iris/ bitstream/10665/77776/1/WHO_MSD_MER_Rev.2012.03_eng.pdf?ua=1

18. Ferreira EAG, Vasconcellos EG, Marques AP. Avaliação da dor e estresse em pacientes com fibromialgia. Rev Bras Reumatol. 2002;42(2):104-10.

19. Kaipper MB, Chachamovich E, Hidalgo MP, Torres IL, Caumo W. Evaluation of the structure of Brazilian State-Trait Anxiety Inventory using a Rasch psychometric approach. J Psychosom Res. 2010;68(3):223-33.

20. Ware JE Jr, Kosinski M, Turner-Bowker DM, Gandek B. User's manual for the SF-12v2 health survey: with a supplement documenting SF$12 \circledR$ health survey. Lincoln, RI: QualityMetric; 2007.

21. Li Y, Guo M, Shi Z, Wu Z, Li J, Ma Q et al. Online near-infrared analysis coupled with MWPLS and SiPLS models for the multi-ingredient and multi-phase extraction of licorice (Gancao). Chin Med. 2015;10:38.

22. Quinkler M, Stewart PM. Hypertension and the cortisol-cortisone shuttle. J Clin Endocrinol Metab. 2003;88(6):2384-92.

23. Zhang M, Ning G, Shou C, Lu Y, Hong D, Zheng X. Inhibitory effect of jujuboside A on glutamate-mediated excitatory signal pathway in hippocampus. Planta Med. 2003; 69(8):692-5.

24. Sinclair-Lian N, Hollifield M, Menache M, Warner T, Viscaya J, Hammerschlag R. Developing a traditional chinese medicine diagnostic structure for post-traumatic stress disorder. J Altern Complement Med. 2006;12(1):45-57.

25. Maciocia G. Os Fundamentos da medicina Chinesa. $2^{a}$ ed. São Paulo: Roca; 2007.

26. Finniss DG, KaptchukTK, Miller F, Benedetti F. Biological, clinical, and ethical advances of placebo effects. Lancet. 2010;375(9715):686-95.

27. Benedetti F, Amanzio M. The placebo response: how words and rituals change the patient's brain. Patient Educ Couns.2011;84(3):413-9.

28. Bensing JM, Verheul W. The silent healer: the role of communication in placebo effects. Patient Educ Couns.2010;80(3):293-9.

29. Colloca L, Lopiano L, Lanotte M, Benedetti F. Overt versus covert treatment for pain, anxiety, and Parkinson's disease. Lancet Neurol. 2004;3(11):679-84.

30. Oken B. Placebo effects: clinical aspects and neurobiology. Brain. 2008;131(Pt 11):2812-23. 